\title{
Quantification of Clostridioides (Clostridium) difficile in feces of calves of different age and determination of predominant Clostridioides difficile ribotype 033 relatedness and transmission between family dairy farms using multilocus variable-number tandem-repeat analysis
}

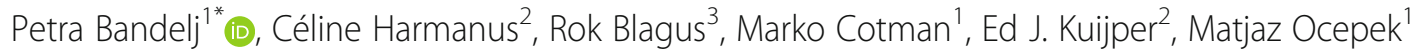
and Modest Vengust ${ }^{1}$

\begin{abstract}
Background: Community acquired Clostridioides (Clostridium) difficile infection (CA-CDI) is a significant health problem in human and veterinary medicine. Animals are often considered as potential reservoirs for CA-CDI. In Europe, family farming is the most predominant farming operation, with a complex interaction between animals and the community. Therefore, it is pertinent to evaluate transmission patterns of $C$. difficile on such prominent European farming model. Fecal samples from calves $(n=2442)$ were collected biweekly over a period of one year on 20 mid-size family dairy farms. Environmental samples $(n=475)$ were collected in a three month interval. Clostridioides difficile was detected using GPCR in 243 fecal samples (243/2442); positive samples were then quantified. Association between prevalence/ load of $C$. difficile and age of the calves was estimated with logistic regression model. Most common $C$. difficile isolate from calves $(n=76)$ and the environment $(n=14)$ was $C$. difficile ribotype 033, which was further analyzed using multilocus variable-number tandem-repeat analysis (MLVA) to assess intra- and between-farm relatedness.

Results: Clostridioides difficile was detected in feces of calves less than $24 \mathrm{~h}$ old. Results showed a non-linear statistically significant decrease in shedding load of $C$. difficile with age $(P<0.0001)$. A nonlinear relationship was also established between the number of calves and the farm $C$. difficile prevalence, whereas the prevalence of $C$. difficile ribotype 033 increased linearly with the number of calves. MLVA revealed close intra-farm relatedness among $C$. difficile ribotypes 033. It also revealed that the between-farms close relatedness of $C$. difficile ribotypes 033 can be a direct result of farm to farm trade of calves.
\end{abstract}

Conclusions: Implementation of better hygiene and management measures on farms may help decrease the risk of spreading CA-CDI between animals and the community. Trading calves older than 3 weeks would decrease the possibility C. difficile dissemination in the community because of lower prevalence and lower load of C. difficile in feces.

Keywords: Clostridioides (Clostridium) difficile, Ribotype 033, community-acquired infection, Dairy cattle, Epidemiology

\footnotetext{
*Correspondence: petra.bandelj@vf.uni-lj.si

'Veterinary faculty, University of Ljubljana, Cesta v Mestni log 47, SI-1115

Ljubljana, Slovenia

Full list of author information is available at the end of the article
}

(c) The Author(s). 2018 Open Access This article is distributed under the terms of the Creative Commons Attribution 4.0 International License (http://creativecommons.org/licenses/by/4.0/), which permits unrestricted use, distribution, and reproduction in any medium, provided you give appropriate credit to the original author(s) and the source, provide a link to the Creative Commons license, and indicate if changes were made. The Creative Commons Public Domain Dedication waiver (http://creativecommons.org/publicdomain/zero/1.0/) applies to the data made available in this article, unless otherwise stated. 


\section{Background}

The increasing number of community acquired Clostridioides difficile infection (CA-CDI) in the past decade has prompted investigations into animal source of CDI $[1,2]$. Several studies have shown that Clostridioides difficile can cause gastrointestinal disease in dogs, horses, piglets and possibly calves [3-9]. It remains unclear, however, if $C$. difficile strains found in animals can cause CDI in humans [9].

Family dairy farms were included in this study. Family farms are the most common operating farming system in the European Union. It represents the sustainable agriculture/agribusiness, and is beneficial for the local community [10]. To estimate the significance of a possible infection source, shedding numbers/load of $C$. difficile had to be quantified and $C$. difficile strains phylogenetically assessed. One of the major risk factor for increased $C$. difficile shedding in the environment is the age of the animal [11-14]. Regardless of the farming management, the prevalence of $C$. difficile has been shown to decrease dramatically with age from 10 to $56 \%$ at and near birth, to $0-3.8 \%$ at the time of slaughter [11, 14-16].

Several studies evaluated the impact of $C$. difficile shedding with calves feces by reporting $C$. difficile prevalence $[8,17-20]$, using longitudinal models $[11,14-16]$, or more recently, enumeration with viable plate counts from feces and carcasses of newborn calves [21]. None of them, however, quantified $C$. difficile in calves in relation to their age, which would indicate the age related risk for $C$. difficile dissemination in the community.

Calves on family farms have been shown to harbor several $C$. difficile ribotypes, with $C$. difficile ribotype 033 being the most prevalent [22]. Most previous reports suggest that C. difficile ribotype 033 is of less clinical importance compared to ribotypes 078, 027, 014 and 012, which are frequently isolated from feces of calves raised in big veal raising operations $[6,11,14,15,18,23,24]$. In humans, due to different genotype and phenotype, ribotype 033induced CDIs might be underdiagnosed [25]. However, one report has associated $C$. difficile ribotype 033 with diarrhea and eventually death in an elderly hospitalized patient in Italy [26], which necessitates further epidemiological assessment of all $C$. difficile ribotypes. Detailed epidemiological investigation can be achieved employing multilocus variable-number tandem-repeat analysis (MLVA), which is the method of choice to identify routes of transmission between patients and the environment [27-29]. This method shows a high level of discrimination and was proven useful for geographical tracking of several outbreak strains of bacteria [30-32].

The aim of this study was to quantify $C$. difficile in calves' feces from birth to six months of age, to determine how much calves contribute to the shedding of $C$. difficile into environment, and to evaluate the relatedness of the most predominant $C$. difficile ribotype 033 between family dairy farms.

\section{Results}

Overall, 243 fecal samples positive for $C$. difficile were collected from 155 calves. A hundred and seven calves $(n=107 / 155,69 \%)$ were positive only once (Additional file 1 and Additional file 2). Forty eight calves $(n=48 /$ $155,31 \%)$ were positive multiple times $(2-6 \times)$ (Table 1 ). Clostridioides difficile prevalence in calves feces decreased significantly with the increasing age of the calves $(P<0.0001)$ (Fig. 1).

\section{Association between $C$. difficile prevalence and the number of calves}

A nonlinear association between the number of calves and the farm prevalence was established for $C$. difficile $(P<0.0001$, Table 2). A steady increase in $C$. difficile prevalence is observed when the number of calves on the farm is up to eight (8), whereas for larger number of animals the $C$. difficile prevalence seems to be only mildly affected by the number of calves (Fig. 2). The prevalence of ribotype 033, however, increases linearly with the number of calves on a farm $(P=0.032$, Table 2$)$.

\section{Quantification}

The load of $C$. difficile/g of calves feces decreased with age $(P<0.0001)$ (Fig. 3). One day old calves had the highest load of $C$. difficile in feces (mean $3.4 \times 10^{6}$ cells $/ g$ feces; $453-13.7 \times 10^{6} \mathrm{C}$. difficile cells/g feces), followed by calves that were 8,11 and 12 days old with the mean of $1.8-1.9 \times 10^{6}$ cells/g feces $\left(50-10.8 \times 10^{6} \mathrm{C}\right.$. difficile cells/g feces). Some calves (less than $24 \mathrm{~h}$ old) were also positive for $C$. difficile and had a mean of $6.2 \times 10^{3} \mathrm{C}$. difficile cells/g feces $\left(126-2.2 \times 10^{4} \mathrm{C}\right.$. difficile cells/g feces).

\section{MLVA}

The minimum spanning tree (Fig. 4) revealed close relatedness among most $C$. difficile ribotype 033. Isolates from calves from the same farm (farm 4, 17 and 18) or local community (farms 5 and 6; farms 14, 15 and 16) were mostly clonal $(\mathrm{STRD}=0)$ or in one clonal complex $(\mathrm{STRD} \leq 2)$. Most calves that were positive for $C$. difficile ribotype 033 several times during the sampling period, harbored the same $C$. difficile clone (T2, T10, T11, T15, T16, T20, T34, T39, T44), had C. difficile isolates in the same clonal complex (T40, T41, T42), or were genetically related with $\mathrm{STRD} \leq 10$ (T27, T28). Two male calves, T20 and T39, from farms 15 and 16 were sold to farm 14. Both were positive with the same clone of $C$. difficile ribotype 033 before and after their relocation. The $C$. difficile clone from calf (T20) was found subsequently in calves born on farm 14 (T21 and T23). Same clone was not present on farm 14 before introduction of calf T20. Clostridioides 
Table 1 Quantification results for C. difficile in feces of calves that were positive multiple times

\begin{tabular}{|c|c|c|c|c|c|c|c|c|c|c|}
\hline Calf & & & & & & & & & & \\
\hline \multirow[t]{2}{*}{1} & Age (days) & 10 & 24 & 38 & 52 & 66 & 80 & 94 & 108 & \\
\hline & No. CD & 102 & 0 & 0 & 0 & 0 & 0 & 88 & 0 & \\
\hline \multirow[t]{2}{*}{2} & Age (days) & 11 & 25 & 39 & 53 & 67 & 81 & 95 & & \\
\hline & No. CD & 0 & 3716 & 0 & 0 & 0 & LOQ & 0 & & \\
\hline \multirow[t]{2}{*}{3} & Age (days) & 12 & 27 & 40 & 54 & 68 & 82 & & & \\
\hline & No. CD & 147 & 578 & 0 & LOQ & 194 & 0 & & & \\
\hline \multirow[t]{2}{*}{4} & Age (days) & 10 & 24 & 38 & 52 & 66 & & & & \\
\hline & No. CD & 0 & 0 & 318 & 174 & 0 & & & & \\
\hline \multirow[t]{2}{*}{5} & Age (days) & 6 & 20 & 34 & & & & & & \\
\hline & No. CD & 2758 & 732 & 0 & & & & & & \\
\hline \multirow[t]{2}{*}{6} & Age (days) & 5 & 19 & 33 & 47 & & & & & \\
\hline & No. CD & 0 & 3300 & 110 & 0 & & & & & \\
\hline \multirow[t]{2}{*}{7} & Age (days) & 2 & 16 & 30 & 44 & & & & & \\
\hline & No. CD & 684 & 0 & LOQ & 0 & & & & & \\
\hline \multirow[t]{2}{*}{8} & Age (days) & 3 & 17 & 31 & 45 & 59 & & & & \\
\hline & No. CD & 295 & 0 & 0 & LOQ & 0 & & & & \\
\hline \multirow[t]{2}{*}{9} & Age (days) & 2 & 16 & 30 & & & & & & \\
\hline & No. CD & 1530 & 441 & 0 & & & & & & \\
\hline \multirow[t]{2}{*}{10} & Age (days) & 5 & 19 & 33 & 47 & 61 & 75 & & & \\
\hline & No. CD & 135,486 & 92 & 0 & 183 & LOQ & 0 & & & \\
\hline \multirow[t]{2}{*}{11} & Age (days) & 5 & 19 & 33 & 47 & 61 & 75 & 89 & 103 & 117 \\
\hline & No. CD & 2676 & 572 & 241 & 0 & 209 & 0 & 0 & LOQ & 0 \\
\hline \multirow[t]{2}{*}{12} & Age (days) & 9 & 23 & 37 & 51 & 65 & & & & \\
\hline & No. CD & 805 & 0 & 942 & 129 & 0 & & & & \\
\hline \multirow[t]{2}{*}{13} & Age (days) & 9 & 22 & 36 & 50 & 92 & 106 & 120 & & \\
\hline & No. CD & 662 & 408 & 1189 & 0 & 0 & 610 & 0 & & \\
\hline \multirow[t]{2}{*}{14} & Age (days) & 1 & 15 & 29 & 43 & 57 & 71 & & & \\
\hline & No. CD & 96,398 & 37,640 & 0 & 0 & LOQ & 0 & & & \\
\hline \multirow[t]{2}{*}{15} & Age (days) & 11 & 25 & 39 & 53 & 67 & & & & \\
\hline & No. CD & 3569 & 2683 & 1901 & LOQ & 0 & & & & \\
\hline \multirow[t]{2}{*}{16} & Age (days) & 1 & 15 & 29 & 43 & 57 & & & & \\
\hline & No. CD & $13,705,988$ & 32,219 & 1623 & 368 & 0 & & & & \\
\hline \multirow[t]{2}{*}{17} & Age (days) & 0 & 14 & 28 & 42 & 56 & 70 & 84 & & \\
\hline & No. CD & 1519 & 0 & LOQ & 0 & 41 & 198 & 0 & & \\
\hline \multirow[t]{2}{*}{18} & Age (days) & 0 & 14 & 29 & 42 & 56 & 70 & 0 & & \\
\hline & No. CD & 0 & 0 & 333 & 0 & 274 & 0 & 0 & & \\
\hline \multirow[t]{2}{*}{19} & Age (days) & 12 & 26 & 40 & 54 & 67 & 82 & & & \\
\hline & No. CD & 0 & 0 & 890 & 65,507 & 2867 & 0 & & & \\
\hline \multirow[t]{2}{*}{20} & Age (days) & 59 & 73 & 87 & 101 & 115 & 129 & 143 & 157 & 171 \\
\hline & No. CD & 0 & 242 & 0 & 0 & 0 & 0 & 0 & LOQ & 0 \\
\hline \multirow[t]{2}{*}{21} & Age (days) & 3 & 17 & 31 & & & & & & \\
\hline & No. $C D$ & 3937 & 4115 & 0 & & & & & & \\
\hline 22 & Age (days) & 1 & 15 & 29 & 43 & 57 & 71 & 85 & & \\
\hline & No. CD & 114 & 0 & 287 & 0 & 0 & 356 & 0 & & \\
\hline
\end{tabular}


Table 1 Quantification results for C. difficile in feces of calves that were positive multiple times (Continued)

\begin{tabular}{|c|c|c|c|c|c|c|c|c|c|c|}
\hline Calf & & & & & & & & & & \\
\hline \multirow[t]{2}{*}{23} & Age (days) & 13 & 27 & 41 & & & & & & \\
\hline & No. CD & 23,470 & 322 & 0 & & & & & & \\
\hline \multirow[t]{2}{*}{24} & Age (days) & 3 & 17 & 31 & & & & & & \\
\hline & No. CD & 54,900 & $4,278,134$ & 0 & & & & & & \\
\hline \multirow[t]{2}{*}{25} & Age (days) & 1 & 15 & 29 & 43 & 57 & 71 & 85 & 99 & 113 \\
\hline & No. CD & 103,235 & 1177 & 0 & 0 & 0 & 0 & 0 & LOQ & 0 \\
\hline \multirow[t]{2}{*}{26} & Age (days) & 11 & 25 & 39 & 53 & 67 & 81 & 95 & 109 & 123 \\
\hline & No. CD & 274,108 & 0 & 0 & 0 & 0 & 0 & 0 & 631 & 0 \\
\hline \multirow[t]{2}{*}{27} & Age (days) & 12 & 25 & 40 & & & & & & \\
\hline & No. CD & $10,811,054$ & 938 & 0 & & & & & & \\
\hline \multirow[t]{2}{*}{28} & Age (days) & 2 & 16 & 30 & 44 & 58 & 72 & & & \\
\hline & No. CD & 0 & 105,727 & 0 & 0 & LOQ & 0 & & & \\
\hline \multirow[t]{2}{*}{29} & Age (days) & 9 & 23 & 37 & 51 & & & & & \\
\hline & No. CD & 2919 & 0 & LOQ & 0 & & & & & \\
\hline \multirow[t]{2}{*}{30} & Age (days) & 7 & 21 & 35 & & & & & & \\
\hline & No. CD & $2,589,994$ & 1152 & 0 & & & & & & \\
\hline \multirow[t]{2}{*}{31} & Age (days) & 4 & 18 & 32 & 46 & & & & & \\
\hline & No. CD & 0 & 806 & 38,702 & LOQ & & & & & \\
\hline \multirow[t]{2}{*}{32} & Age (days) & 7 & 21 & 35 & & & & & & \\
\hline & No. CD & 9630 & 1827 & 0 & & & & & & \\
\hline \multirow[t]{2}{*}{33} & Age (days) & 6 & 20 & 34 & & & & & & \\
\hline & No. CD & $1,587,504$ & 5278 & 0 & & & & & & \\
\hline \multirow[t]{2}{*}{34} & Age (days) & 9 & 23 & 37 & 51 & 65 & 79 & 93 & & \\
\hline & No. CD & $3,906,984$ & 1316 & 1055 & 0 & 0 & 783 & 0 & & \\
\hline \multirow[t]{2}{*}{35} & Age (days) & 13 & 27 & 42 & 55 & 69 & 83 & 97 & & \\
\hline & No. CD & 53,735 & 66,424 & LOQ & 20,396 & 0 & LOQ & 0 & & \\
\hline \multirow[t]{2}{*}{36} & Age (days) & 12 & 26 & 40 & 54 & 68 & & & & \\
\hline & No. CD & 842,730 & 1084 & 0 & 304 & 0 & & & & \\
\hline \multirow[t]{2}{*}{37} & Age (days) & 3 & 17 & 31 & 45 & 59 & & & & \\
\hline & No. CD & $7,260,792$ & 1346 & 632 & LOQ & 0 & & & & \\
\hline \multirow[t]{2}{*}{38} & Age (days) & 5 & 19 & 33 & 47 & 61 & 75 & & & \\
\hline & No. CD & 11,629 & 137 & 3715 & 0 & 723 & 0 & & & \\
\hline \multirow[t]{2}{*}{39} & Age (days) & 34 & 48 & 62 & 76 & 90 & & & & \\
\hline & No. CD & 294 & 0 & 0 & LOQ & 0 & & & & \\
\hline \multirow[t]{2}{*}{40} & Age (days) & 9 & 23 & 37 & 51 & & & & & \\
\hline & No. CD & 207 & LOQ & LOQ & 0 & & & & & \\
\hline \multirow[t]{2}{*}{41} & Age (days) & 10 & 24 & 38 & & & & & & \\
\hline & No. CD & 428 & 401 & 0 & & & & & & \\
\hline \multirow[t]{2}{*}{42} & Age (days) & 6 & 20 & 34 & & & & & & \\
\hline & No. CD & 28,022 & 779 & 0 & & & & & & \\
\hline \multirow[t]{2}{*}{43} & Age (days) & 20 & 34 & 48 & 62 & 76 & 90 & 104 & 118 & 132 \\
\hline & No. CD & 0 & 30,971 & 0 & 0 & 0 & 0 & 0 & 0 & LOQ \\
\hline 44 & Age (days) & 9 & 22 & 37 & & & & & & \\
\hline & No. CD & $3,593,368$ & 4064 & 0 & & & & & & \\
\hline
\end{tabular}


Table 1 Quantification results for C. difficile in feces of calves that were positive multiple times (Continued)

\begin{tabular}{|c|c|c|c|c|c|c|c|}
\hline \multicolumn{8}{|c|}{ Calf } \\
\hline \multirow[t]{2}{*}{45} & Age (days) & 8 & 21 & 36 & & & \\
\hline & No. CD & 678,040 & 1627 & 0 & & & \\
\hline \multirow[t]{2}{*}{46} & Age (days) & 11 & 25 & 39 & 53 & 67 & 81 \\
\hline & No. CD & 129 & 13,724 & 0 & 0 & 537 & 0 \\
\hline \multirow[t]{2}{*}{47} & Age (days) & 0 & 14 & 28 & 42 & 56 & \\
\hline & No. CD & 0 & $3,200,151$ & 7897 & 2160 & 0 & \\
\hline \multirow[t]{2}{*}{48} & Age (days) & 12 & 26 & 40 & & & \\
\hline & No. CD & 48,901 & 8297 & 0 & & & \\
\hline
\end{tabular}

LOQ under the limit of quantification; CD Clostridioides difficile

difficile ribotype 033 clone recovered from calf T39 was introduced from farm 15 to farm 14 . However, the same clone wasn't found in any other calves born on farm 14 .

The same MLVA profile $(n=6)$ that was identified from the environmental samples, could be linked to the $C$. difficile ribotype 033 isolated form calves of the same farm or from the same geographical area (Fig. 4). Several $(n=7)$ were more genetically related to isolates from other unrelated farms. Interestingly, $C$. difficile ribotype 033 recovered from a barn fly on farm 5, had the same MLVA profile as the $C$. difficile recovered from calves (T19, T26) on an epidemiologically unrelated farm (farm 16).

\section{Discussion}

The aim of the study was to quantify $C$. difficile in feces of calves and to evaluate the relatedness of the most common $C$. difficile ribotype 033 between economically related and unrelated family dairy farms.

We also established that the $C$. difficile prevalence is non-linearly related to the number of calves on the farm. While a steady increase in $C$. difficile prevalence is observed up to a certain number of animals, it then remains roughly at the same level, when the number of animals increases further. The prevalence of $C$. difficile ribotype 033, however, is linear to the number of calves on the farm.

Newborn calves had the highest prevalence and load of C. difficile /g feces, which decreased over time. The decrease in prevalence over the increasing age of animals has previously been established $[11,14]$. However, this is the first report associating the fecal load of $C$. difficile with age of calves. Repeated sampling of the same calves over their first 6 months of life has also shown that calves can

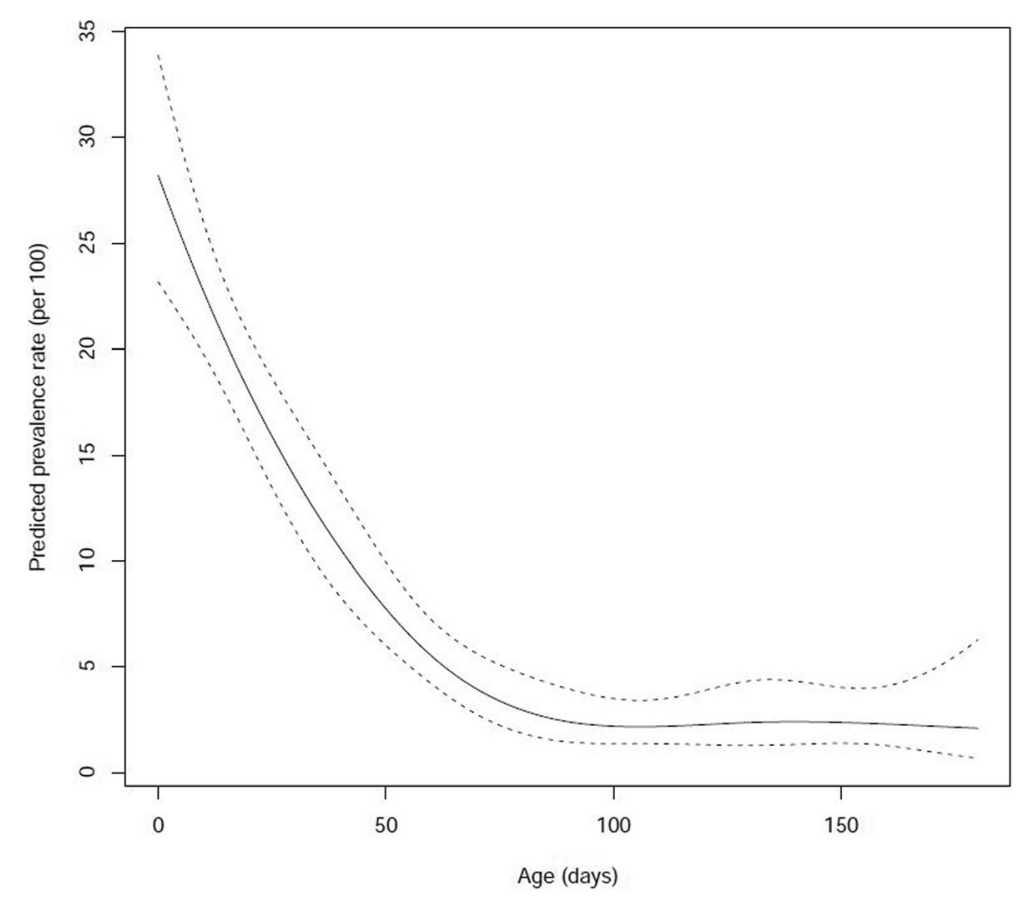

Fig. 1 C. difficile prevalence rates in calves from 0 to 180 days old per 100 and 95\% confidence intervals 
Table 2 The association between the prevalence of $C$. difficile and ribotype 033 and the number of calves

\begin{tabular}{lllllrr}
\hline Outcome & Variable & Estimate & SE & $p$ & (Exp)estimate & $95 \% \mathrm{Cl}$ \\
\hline C. difficile & Number of Calves & & & $<0.0001$ & & \\
& linear & 0.33 & 0.08 & $<0.0001$ & 1.39 & $0.1 .18-1.66$ \\
& non-linear & -0.39 & 0.16 & 0.0174 & $0.48-0.93$ \\
& Time of sampling & 0.02 & 0.01 & 0.0251 & 1.02 & $1.01-1.04$ \\
Ribotype 033 & Number of Calves & 0.13 & 0.06 & 0.0323 & 1.13 & $1.01-1.27$ \\
& Time of sampling & 0.01 & 0.01 & 0.4932 & 1.01 & $0.98-1.04$
\end{tabular}

The time of sampling is included only to control for the effect of the meteorolical season. The linear/non-linear effect of $C$. difficile prevalence should be estimated from Fig. 2

SE Standard error

be positive for $C$. difficile more than once with the same or different ribotype or MLVA profile.

In this study calves aged 1 day and around 12 days had the highest load of $C$. difficile cells/g feces. Interestingly, some calves sampled in the first $24 \mathrm{~h}$ after birth, were also shedding $C$. difficile with feces (meconium). This is in concordance with Hopman et al. [33], who demonstrated $\mathrm{CD}$ shedding in piglets after their first hour of life and the prevalence at day one increased from 8.3 to $62 \%$.

The predominance of $C$. difficile ribotype 033 on sampled farms gave us the opportunity to investigate the epidemiology of $C$. difficile between economically related and unrelated family dairy farms. Most studies to date were performed on big veal farms which congregate large numbers of calves of different geographical origins
$[11,34]$. Our study included only family farms located in a driving distance between each other $(\leq 2 \mathrm{~h}$ from farm to farm), where some are economically connected with trading of calves or products. As expected the $C$. difficile isolates 033 from the same farm sampled on different dates or different calves were clonal or in the same clonal complex as was recently found also in piglets [35]. The similarity was also shown in $C$. difficile isolates from farm sharing the same private farm road (farm 5 and 6) or trading of the male calves (farm 14 and 15; farm 14 and 16). We even suggested a possible transmission of $C$. difficile from one farm (farm 16) to another (farm 14) through a colonized calf, where the calf remained colonized for several weeks, shedding $C$. difficile in the environment. Two other calves, born on the farm (farm 14), and later throughout the study placed in the same individual box as the

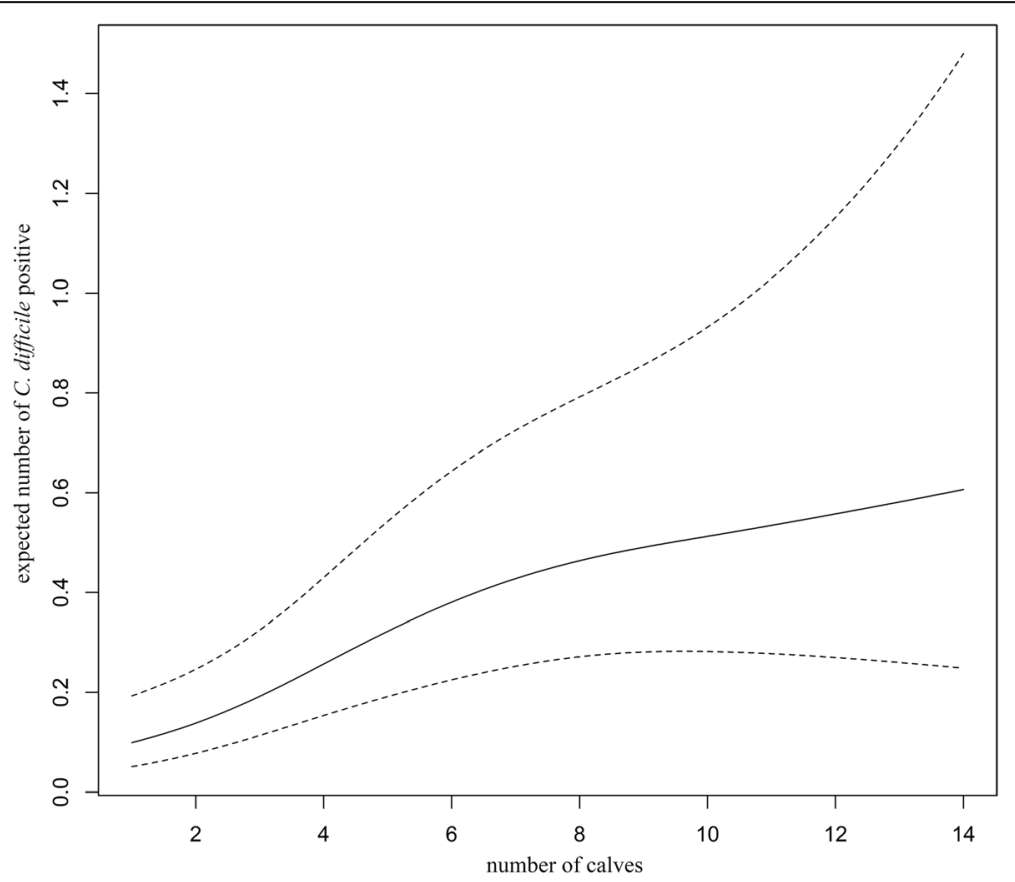

Fig. 2 Expected prevalence of $C$. difficile positive calves versus the total numer of calves on the farms 


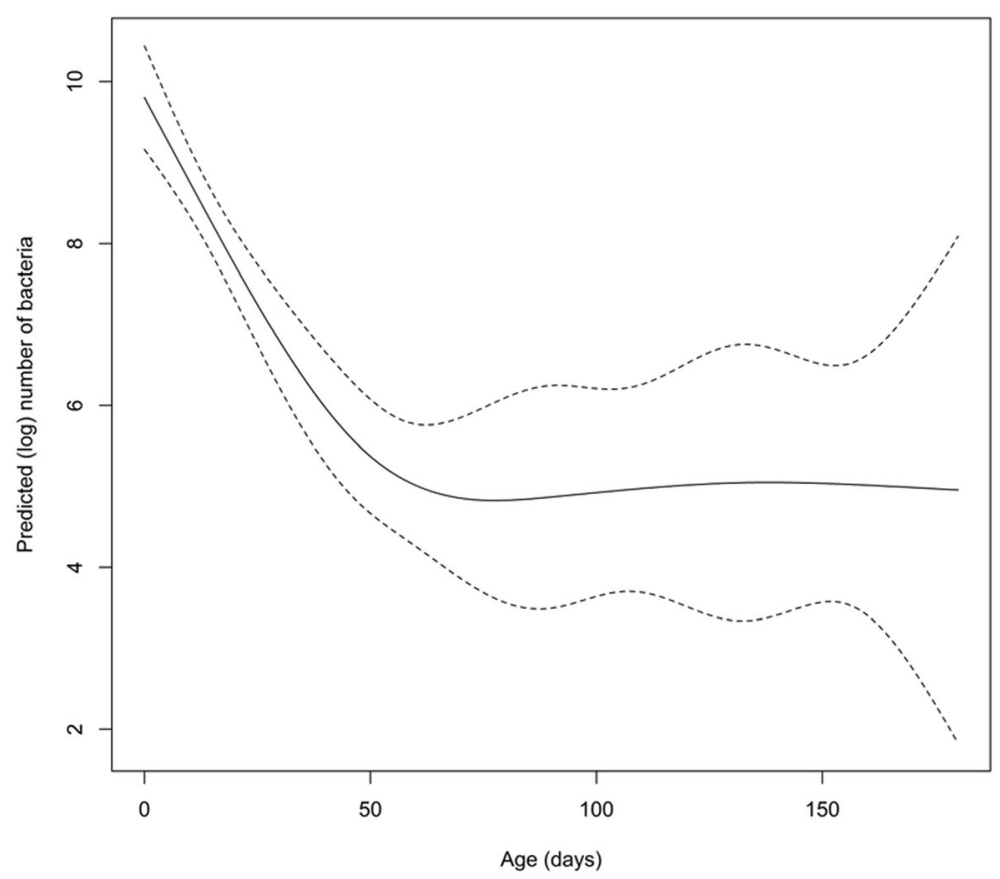

Fig. 3 Predicted log transformed load of C. difficile and age (in days) of calves and 95\% confidence intervals

colonized calf, were found colonized with the same clonal C. difficile isolate. This is the first suggestion of a possible calf to calf and farm to farm transmission of $C$. difficile. However, due to lower sensitivity of the culture method compared to qPCR [36] and the history of calf trading between these two farms, we could also assume that transmission of this clonal $C$. difficile isolate could have happened before the start of our study.

Interestingly, one calf (T19 from farm 16) was positive for three consecutive times with $C$. difficile ribotype 033, which were not related $(\mathrm{STRD} \leq 10)$ or clonal $(\mathrm{STRD} \leq 2)$. Calves have been shown to harbor different $C$. difficile ribotypes during different life stages [14]. Results of this study also indicate that they can be colonized with different MLVA types of the same $C$. difficile ribotype. Some environmental $C$. difficile strains (farm 5 and farms 2, 13, $14,15)$ were clonal to strains from calves found on seemingly unrelated farms (farms 2, 4, 16 and farms 5, 6). There might be some epidemiological connection that we are unaware of, since farms have fields scattered across the area and sometimes cross paths with each other. Or simply, the high relatedness of all the samples tested could be the consequence of less natural variability in ribotype 033 than in other ribotypes as stated in the article from Bakker et al. [28]. Another possibility that could contribute to the spreading of different MLVA types of C. difficile in the community is flying insects. In our study, we found a fly on farm 5 to harbor the same clone of $C$. difficile as calves on farm 16 (distance between farms approximately $5 \mathrm{~km}$ ).

\section{Conclusions}

In conclusion, we demonstrated that calves can shed high loads of $C$. difficile from birth and that there is a non-linear statistically significant decrease of $C$. difficile prevalence and load with age. The superior prevalence of ribotype 033 compared to other ribotypes gained from a previous study [22] gave us the opportunity to assess the epidemiology of $C$. difficile between farms. We have suggested a farm to farm transmission through trading of a colonized calf. However, environmental and calves C. difficile strains from the same farm weren't always related. Nevertheless, implementing better hygiene and management measures may help decrease the risk of spreading CA-CDI between animals and the community. Trading calves older than 3 weeks would decrease the possibility for $C$. difficile dissemination in the community not only because of lower prevalence, but also because of lower load of $C$. difficile in feces.

\section{Methods \\ Material}

Twenty mid-size family dairy farms with 9 to 40 cows located in Slovenian Prealps were included in this study. Farms run by family member only were selected based on several factors; location, accessibility, farmers compliance and number of dairy cows in production. All data with regards to the farms characteristics were described before [22]. Feces from all calves on the farm were collected at the time of sampling. All calves had mandatory ear tags used for individual identification. Fecal samples 


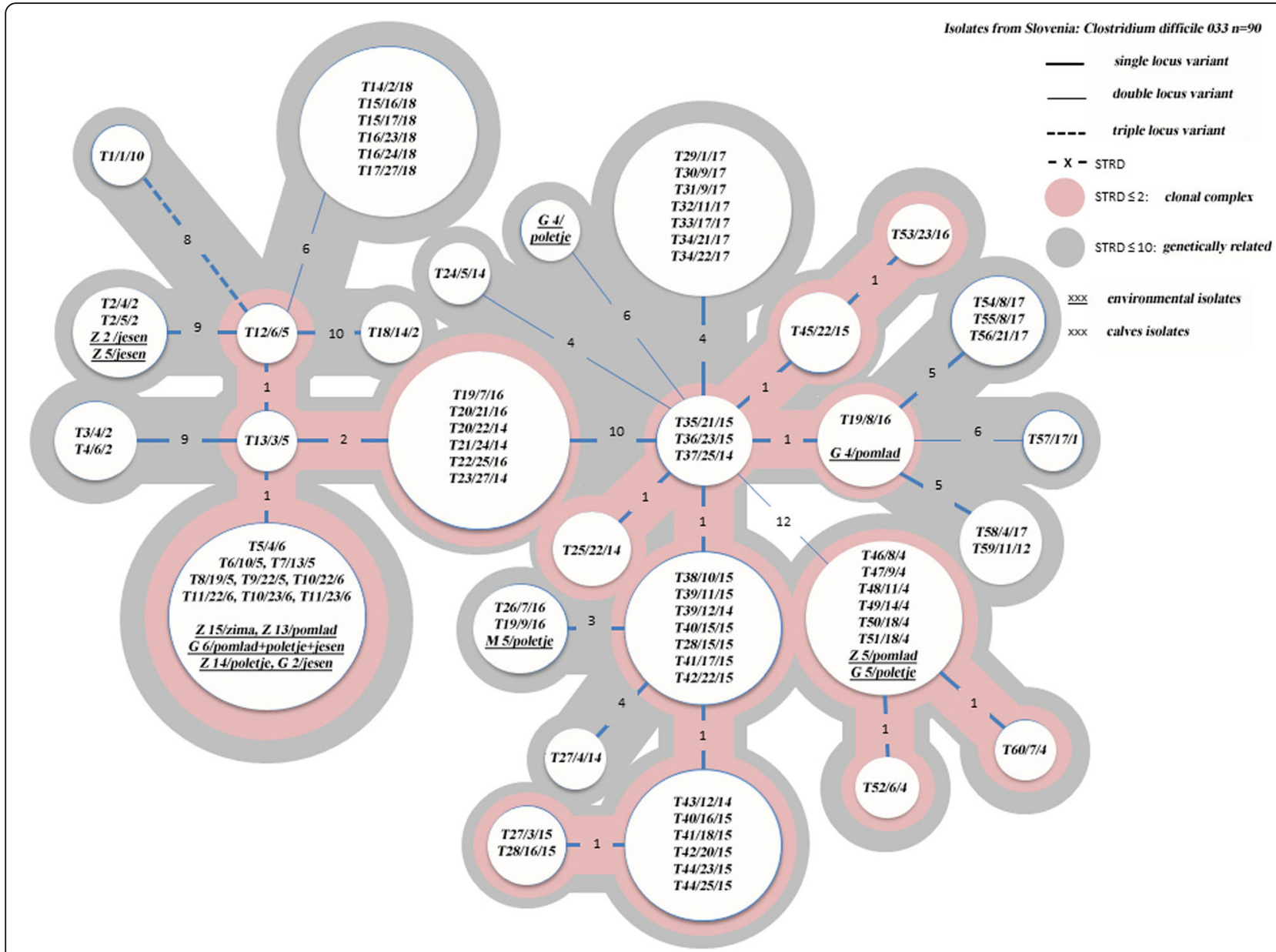

Fig. 4 Minimum spaning tree for C. difficile ribotype 033 isolated from calves feces and environmental samples: Clonal (STRD =0), clonal complex (STRD $\leq 2$ ), genetically related (STRD $\leq 10$ ). Legend: $T n / n / n$ - individual calf number/sampling time/farm; $Z n$ - soil sample on farm $n ; G n-$ manure sample from farm $\mathrm{n} ; \mathrm{M} \mathrm{n}$ - flies from farm $\mathrm{n}$

from calves $(n=2442)$ were collected individually from the rectum with clean latex gloves in two weeks intervals over a period of one year [22]. From these samples, 243 were positive for $\mathrm{CD}$ with $\mathrm{qPCR}$ and subsequently, 76 were identified as $\mathrm{CD}$ ribotype 033 with selective culture and ribotyping [22].

Environmental samples collected on every farm during each meteorological season were soil, manure, water, feed, other animals present on the farm, barn fly (Stomoxys calcitrans) and droppings from Barn Swallow (Hirundo rustica) [22]. Fourteen environment samples (manure = 7 , soil $=6$, barn fly $($ Stomoxys calcitrans $)=1$ ) that were used in this study, were identified as CD ribotype 033 by selective culture and ribotyping [22].

\section{Methods}

\section{Quantification of C. difficile in calves fecal samples}

Calves fecal samples were tested for $C$. difficile specific fragment of $16 \mathrm{~S}$ gene using a quantitative real-time PCR (qPCR) reported by Bandelj et al. [36] with a LOD and
LOQ of 7.72 CD cells/g feces and 77.2 CD cells/g feces, respectively. Samples $(n=243)$ were retested in duplicates and in 1:10 dilutions to evaluate for possible inhibitory effects of the matrix.

\section{Multilocus variable-number tandem-repeat analysis (MLVA) of $\mathrm{C}$. difficile ribotype 033}

For MLVA, we used $90 \mathrm{C}$. difficile ribotype 033 isolates belonging to 76 calves and 14 environment samples. The $C$. difficile isolates were tested for relatedness with a modified MLVA. All MLVA PCRs for six loci were performed in singleplex format as described previously $[27,28]$. To determine the genetic distance between isolates the minimum spanning tree was constructed. The number of differing loci and the summed tandem repeat difference (STRD) was used as coefficients for the genetic distance in BioNumerics, version 7.0 (Applied Maths) as previously described [37]. Genetically related were isolates with a STRD $\leq 10$, whereas clonal complexes were defined by a $S T R D \leq 2$. 


\section{Statistical analysis}

The association between the prevalence and load of bacteria of $C$. difficile and age was estimated by the logistic regression model; the unit of analysis was an animal. Restricted cubic splines (using 5 knots) were used to account for a highly non-linear association between the prevalence/load of bacteria and age.

The association between the number of $C$. difficile and ribotype 033 positives and number of calves was estimated with Poisson generalized linear model with log link, including farm ID as a random effect (random intercept) and time of sampling as a fixed effect to account for repeated measurements; here the unit of analysis was a farm. For C. difficile a non-linear association was modeled by using restricted cubic splines with 3 knots. A possible non-linear association for ribotype 033 was also considered, however since the non-linear effect was not significant $(P>0.05)$, the results assuming a linear association are presented.

A $p$-value of less than 0.05 was considered as statistically significant. The analysis was performed with $\mathrm{R}$ language for statistical computing ( $\mathrm{R}$ version 3.0.3) [38].

Additional file 1: Quantification results for $C$. difficile in feces of calves with single positive sample (0-21 days). (DOCX $35 \mathrm{~kb}$ )

Additional file 2: Quantification results for $C$. difficile in feces of calves with single positive sample (22-180 days). (DOCX 33 kb)

\section{Abbreviations}

CA-CDI: Community acquired Clostridioides (Clostridium) difficile infection; CDI: Clostridioides (Clostridium) difficile infection; MLVA: Multilocus variable-number tandem-repeat analysis; qPCR: quantitative real-time PCR; STRD: Summed tandem repeat difference

\section{Acknowledgments}

The authors thank Alenka Magdalena Usenik, Milojka Setina, dr. Katarina Logar, dr. Tina Pirs, dr. Darja Kusar, mag. Maja Kavalic, dr. Maja Rupnik and all participating farmers for their valuable assistance.

\section{Funding}

This work was financed with the support of Slovenian National Research Agency (grant nos. J4-2236, J3-4298, P4-0092, P4-0053 and grant for young researchers $-P$. Bandelj).

\section{Availability of data and materials}

Relevant datasets used and/or analysed during the current study are included in this published article [and its additional files]. Raw data not included in this article are available from the corresponding author on reasonable request. A detailed description of how the materials were gained is appropriately referenced within this published article.

\section{Authors' contributions}

The study was designed by PB, MV and MO. The qPCR and MLVA analysis were performed by $\mathrm{PB}, \mathrm{MC}$ and $\mathrm{CH}$. Interpretation of MLVA data was performed by EJK and $\mathrm{CH}$. The statistical analysis was performed by RB and assessed by RB and MV. The manuscript was written by PB, MV and RB. It was critically reviewed by EJK, MO, $\mathrm{CH}$ and $\mathrm{MC}$. All authors read and approved the final manuscript.

\section{Competing interest}

The authors declare that they have no competing interests.

\section{Ethics approval}

This study underwent ethical review and was given approval by the National Animal Care Committee at the Ministry of Agriculture, Forestry and Food - Slovenian Veterinary Administration. A written consent from herd owners was obtained for sample collection and the use of cattle data in this study.

\section{Consent for publication}

Not applicable.

\section{Publisher's Note}

Springer Nature remains neutral with regard to jurisdictional claims in published maps and institutional affiliations.

\section{Author details}

${ }^{1}$ Veterinary faculty, University of Ljubljana, Cesta v Mestni log 47, SI-1115 Ljubljana, Slovenia. ${ }^{2}$ Department of Medical Microbiology, Center of Infectious Diseases, Leiden University Medical Center, Leiden, Netherlands. ${ }^{3}$ Institute for biostatistics and Medical informatics, University of Ljubljana, Vrazov trg 2, Sl-1104 Ljubljana, Slovenia.

Received: 29 May 2018 Accepted: 16 September 2018 Published online: 01 October 2018

\section{References}

1. Wilcox MH, Mooney L, Bendall R, Settle CD, Fawley WN. A case-control study of community-associated Clostridium difficile infection. J Antimicrob Chemother. 2008;62:388-96.

2. Khanna S, Pardi DS, Aronson SL, Kammer PP, Orenstein R, St Sauver JL, Harmsen WS, Zinsmeister AR. The epidemiology of community-acquired Clostridium difficile infection: a population-based study. Am J Gastroenterol. 2012;107:89-95.

3. Weese JS, Staempfli HR, Prescott JF, Kruth SA, Greenwood SJ, Weese HE. The roles of Clostridium difficile and enterotoxigenic Clostridium perfringens in diarrhea in dogs. J Vet Intern Med. 2001;15:374-8.

4. Weese JS, Staempfli HR, Prescott JF. A prospective study of the roles of Clostridium difficile and enterotoxigenic Clostridium perfringens in equine diarrhoea. Equine Vet J. 2001;33:403-9.

5. Yaeger MJ, Kinyon JM, Songer JG. A prospective, case control study evaluating the association between Clostridium difficile toxins in the colon of neonatal swine and gross and microscopic lesions. J Vet Diagn Investig. 2007;19:52-9.

6. Rodriguez-Palacios A, Staempfli HR, Duffield T, Peregrine AS, Trotz-Williams LA, Arroyo LG, Brazier JS, Weese JS. Clostridium difficile PCR ribotypes in calves, Canada. Emerg Infect Dis. 2006;12:1730-6.

7. Songer JG, Anderson MA. Clostridium difficile: an important pathogen of food animals. Anaerobe. 2006:12:1-4.

8. Hammitt MC, Bueschel DM, Keel MK, Glock RD, Cuneo P, DeYoung DW, Reggiardo C, Trinh HT, Songer JG. A possible role for Clostridium difficile in the etiology of calf enteritis. Vet Microbiol. 2008;127:343-52.

9. Keessen EC, Gaastra W, Lipman LJA. Clostridium difficile infection in humans and animals, differences and similarities. Vet Microbiol. 2011;153:205-17.

10. Agriculture and rural development - Family farming. European Commission. 2015. http://ec.europa.eu/agriculture/family-farming/index_en.htm. Accessed 20 May 2015.

11. Costa MC, Stämpfli HR, Arroyo LG, Pearl DL, Weese JS. Epidemiology of Clostridium difficile on a veal farm: prevalence, molecular characterization and tetracycline resistance. Vet Microbiol. 2011;152:379-84.

12. Hawken P, Weese JS, Friendship R, Warriner K. Longitudinal study of Clostridium difficile and methicillin-resistant Staphylococcus aureus associated with pigs from weaning through to the end of processing. J Food Prot. 2013;76:624-30.

13. Weese JS, Wakeford T, Reid-Smith R, Rousseau J, Friendship R. Longitudinal investigation of Clostridium difficile shedding in piglets. Anaerobe. 2010;16:501-4.

14. Zidaric V, Pardon B, dos Vultos T, Deprez P, Brouwer MSM, Roberts AP, Henriques AO, Rupnik M. Different antibiotic resistance and sporulation properties within multiclonal Clostridium difficile PCR ribotypes 078, 126, and 033 in a single calf farm. Appl Environ Microbiol. 2012;78:8515-22.

15. Rodriguez-Palacios A, Pickworth C, Loerch S, LeJeune JT. Transient fecal shedding and limited animal-to-animal transmission of Clostridium difficile by naturally infected finishing feedlot cattle. Appl Environ Microbiol. 2011; 77:3391-7. 
16. Knight DR, Thean S, Putsathit P, Fenwick S, Riley TV. Cross-sectional study reveals high prevalence of Clostridium difficile non-PCR ribotype 078 strains in Australian veal calves at slaughter. Appl Environ Microbiol. 2013;79:2630-5.

17. Pirs T, Ocepek M, Rupnik M. Isolation of Clostridium difficile from food animals in Slovenia. J Med Microbiol. 2008;57:790-2.

18. Koene MGJ, Mevius D, Wagenaar JA, Harmanus C, Hensgens MPM, Meetsma AM, Putirulan FF, Van Bergen MAP, Kuijper EJ. Clostridium difficile in Ducth animals: their presence, characteristics and similarities with human isolates. Clin Microbiol Infect. 2012;18:778-4.

19. Romano V, Albanese F, Dumontet S, Krovacek K, Petrini O, Pasquale V. Prevalence and genotypic charaterization of Clostridium difficile from ruminants in Switzerland. Zoonoses Public Health. 2012;59:545-8.

20. Rodriguez C, Taminiau B, Van Broeck J, Avesani V, Delmée M, Daube G. Clostridium difficile in young farm animals and slaughter animals in Belgium. Anaerobe. 2012;18:621-5.

21. Knight DR, Putsathis P, Elliott B, Riley TV. Contamination of Australian newborn calf carcasses at slaughter with Clostridium difficile. Clin Microbiol Infect. 2016;22:266.e1-7.

22. Bandelj P, Blagus R, Briski F, Frlic O, Vergles Rataj A, Rupnik M, Ocepek M, Vengust M. Identification of risk factors influencing Clostridium difficile prevalence in middle-size dairy farms. Vet Res. 2016:47:41.

23. Keel K, Brazier JS, Post KW, Weese JS, Songer JG. Prevalence of PCR Ribotypes among Clostridium difficile isolates from pigs, calves, and other species. J Clin Microbiol. 2007:45:1963-4.

24. Schneeberg A, Neubauer H, Schmoock G, Grossmann E, Seyboldt C. Presence of Clostridium difficile PCR ribotype clusters related to 033, 078 and 045 in diarrheic calves in Germany. J Med Microbiol. 2013;62:1190-8.

25. Krutova M, Wilcox MH, Kuijper EJ. The pitfalls of laboratory diagnostics of Clostridium difficile infection. Clin Microbiol Infect. 2018;24:682-3.

26. Grandesso S, Arena F, Eseme FE, Panese S, Henrici De Angelis L, Spigaglia P, Barbanti F, Rossolini GM. Clostridium difficile ribotype 033 colitis in a patient following broad-spectrum antibiotic treatment for KPC-producing Klebsiella pneumoniae infection, Italy. New Microbiol. 2016;39:235-6.

27. van den Berg RJ, Schaap I, Templeton KE, Klaassen CH, Kuijper EJ. Typing and subtyping of Clostridium difficile isolates by using multiple-locus variable-number tandem-repeat analysis. J Clin Microbiol. 2007:45:1024-8.

28. Bakker D, Corver J, Harmanus C, Goorhuis A, Keessen EC, Fawley WN, Wilcox $\mathrm{MH}$, Kuijper EJ. Relatedness of human and animal Clostridium difficile PCR ribotype 078 isolates determined on the basis of multilocus variablenumber tandem-repeat analysis and tetracycline resistance. J Clin Microbiol. 2010;48:3744-9.

29. Rodriguez C, Avesani V, Taminiau B, Van Broeck J, Brévers B, Delmée M, Daube $\mathrm{G}$. Investigation of Clostridium difficile interspecies relatedness using multilocus sequence typing, multilocus variable-number tandem-repeat analysis and antimicrobial susceptibility testing. Vet J. 2015;206:349-55.

30. Killgore G, Thompson A, Johnson S, Brazier J, Kuijper E, Pepin J, Frost EH, Savelkoul P, Nicholson B, van den Berg RJ, Kato H, Sambol SP, Zukowski W, Woods C, Limbago B, Gerding DN, McDonald LC. Comparison of seven techniques for typing international epidemic strains of Clostridium difficile: restriction endonuclease analysis, pulsed-field gel electrophoresis, PCRribotyping, multilocus sequence typing, multilocus variable-number tandemrepeat analysis, amplified fragment length polymorphism, and surface layer protein a gene sequence typing. J Clin Microbiol. 2008;46:431-7.

31. Manzoor SE, Tanner HE, Marriott CL, Brazier JS, Hardy KJ, Platt S, Hawkey PM. Extended multilocus variable-number tandem-repeat analysis of Clostridium difficile correlates exactly with ribotyping and enables identification of hospital transmission. J Clin Microbiol. 2011;49:3523-30.

32. Eyre DW, Fawley WN, Best EL, Griffiths D, Stoesser NE, Crook DW, Peto TE, Walker AS, Wilcox MH. Comparison of multilocus variable-number tandemrepeat analysis and whole-genome sequencing for investigation of Clostridium difficile transmission. J Clin Microbiol. 2013;51:4141-9.

33. Hopman NE, Keessen EC, Harmanus C, Sandersm IM, van Leengoed LA, Kuijper EJ, Lipman LJ. Acquisition of Clostridium difficile by piglets. Vet Microbiol. 2011;149:186-92.

34. Magistrali CF, Maresca C, Cucco L, Bano L, Drigo I, Filippini G, Dettori A, Broccatelli S, Pezzotti G. Prevalence and risk factors associated with Clostridium difficile shedding in veal calves in Italy. Anaerobe. 2015;33:42-7.

35. Krutova M, Zouharova M, Matejkova J, Tkadlec J, Krejčí J, Faldyna M, Nyc O Bernardy J. The emergence of Clostridium difficile PCR ribotype 078 in piglets in the Czech Republic clusters with Clostridium difficile PCR ribotype 078 isolates from Germany, Japan and Taiwan. Int J Med Microbiol. 2018.
36. Bandelj P, Logar K, Usenik AM, Vengust M, Ocepek M. An improved qPCR protocol for rapid detection and quantification of Clostridium difficile in cattle feces. FEMS Microbiol Lett. 2013;341:115-21.

37. Goorhuis A, Bakker D, Corver J, Debast SB, Harmanus C, Notermans DW, Bergwerff AA, Dekker FW, Kuijper EJ. Emergence of Clostridium difficile infection due to a new hypervirulent strain, polymerase chain reaction ribotype 078. Clin Infect Dis. 2008;47:1162-70.

38. R Core Team. R: a language and environment for statistical computing. $R$ Foundation for statistical computing, Vienna. 2014. https://doi.org/10.1016/j. ijmm.2018.05.006. http://www.R-project.org/. Accessed 20 Feb 2017.

\section{Ready to submit your research? Choose BMC and benefit from:}

- fast, convenient online submission

- thorough peer review by experienced researchers in your field

- rapid publication on acceptance

- support for research data, including large and complex data types

- gold Open Access which fosters wider collaboration and increased citations

- maximum visibility for your research: over $100 \mathrm{M}$ website views per year

At $\mathrm{BMC}$, research is always in progress.

Learn more biomedcentral.com/submissions 